\title{
ANALISIS PELAYANAN ADMINISTRASI DAN TANGGUNG JAWAB PETUGAS TIKET KAPAL JASA TRANSPORTASI LAUT TERHADAP KEPUASAN PENUMPANG PADA PT. PELAYARAN NASIONAL INDONESIA CABANG SURABAYA
}

\author{
${ }^{1)}$ Nur Widyawati \\ ${ }^{2)}$ Ira Zulviana \\ ${ }^{1,2)}$ STIA dan Manajemen Kepelabuhan Barunawati Surabaya \\ 1) nur.widyawati@stiamak.ac.id \\ ${ }^{2)}$ zulvianaira@gmail.com
}

\begin{abstract}
ABSTRAK
Penelitian ini bertujuan untuk mengetahui pengaruh pelayanan administrasi dan tanggung jawab terhadap kepuasan penumpang. Penelitian ini merupakan penelitial kuantitatif. Populasi yang digunakan adalah seluruh penumpang yang menggunakan jasa transportasi laut pada PT. Pelayaran Nasional Indonesia dengan jumlah sampel yang digunakan sebagai penelitian sebanyak 56 penumpang, untuk menganalisis data digunakan teknik analisis regresi linier berganda. Hasil perhitungan menggunakan analisis regresi linier berganda. Pada uji $\mathrm{t}$, diperoleh nilai koefisiensi regresi untuk masing-masing variabel bebas adalah -,005 untuk pelayanan administrasi $\left(\mathrm{X}_{1}\right)$ dan 0,399 untuk tanggung jawab $\left(\mathrm{X}_{2}\right)$ nilai koefisiensi regresi yang positif menunjukkan bahwa hubungan dari masing-masing variabel bebas adalah positif. Hasil uji $\mathrm{t}$ pada variabel pelayanan administrasi menunjukkan $t_{\text {hitung }}$ sebesar $-0,34$ lebih kecil $t_{\text {tabel }}$ sebesar 0,401 ( $\alpha$ sebesar 0,973 > 0,005) sehingga secara parsial pelayanan administrasi sebagai variabel bebas $\mathrm{X}_{1}$ tidak berpengaruh terhadap kepuasan penumpang sedangkan tanggung jawab sebagai variabel bebas $\mathrm{X}_{2}$ memberikan pengaruh positif terhadap kepuasan penumpang yaitu dengan dengan $t_{\text {hitung }} 3,105$ lebih besar dari $t_{\text {tabel }} 2,005$ ( $\alpha$ sebesar $\left.0,003<0,05\right)$. Uji ANOVA pelayanan administrasi $\left(\mathrm{X}_{1}\right)$, tanggung jawab $\left(\mathrm{X}_{2}\right)$ berpengaruh signifikan secara simultan terhadap kepuasan penumpang (Y) dengan nilai $\alpha$ sebesar $0,010<0,05$.
\end{abstract}

Kata Kunci : Pelayanan Administrasi, Tanggung jawab, Kepuasan Penumpang.

\section{PENDAHULUAN}

PT. Pelayaran Nasional Indonesia atau sering disingkat PT. Pelni adalah salah satu badan Usaha Milik Negara (BUMN) yang bergerak dibidan perkapalan dan non perkapalan. Yang bergerak dibidang perkapalan meliputi jasa angkutan penumpang, dan muatan barang antar pulau sedangkan untuk non perkapalan meliputi usaha keagenan, usaha galangan surya, usaha sewa kantor, dan usaha perhotelan. Dalam dunia usaha, tujuan utama dari suatu perusahaan adalah memperoleh laba yang optimal demi memaksimalkan tumbuh kembang perusahaan. Sumber pendapatan atau laba perusahaan diperoleh dari kegiatan penjualannya. Dalam melaksanakan penjualan, sistem administrasi sangat penting untuk melancarkan transaksi penjualan serta sebagai suatu pendukung dalam mencapai tujuan perusahaan.

Transaksi penjualan yang baik didukung dengan sistem administrasinya yang efektif dan efisien. Adanya administrasi dalam suatu perusahaan juga berperan dalam pengambilan keputusan demi perkembangan perusahaan. Dalam hal pejualan, administrasi yang baik bertujuan untuk mencapai transaksi penjualan yang efektif sehingga diperoleh pendapatan yang optimal serta pelayanan yang memuaskan kepada pelanggan atau pembeli. Administrasi penjualan sangat penting untuk mendukung penyajian berbaga informasi mengenai penjualan. Kebutuhan akan informasi dalam suatu perusahaan sangat tinggi karena berhubungan dengan penentuan dan pengambilan keputusan dalam menetapkan kebijakan perusahaan. Karena pentingnya informasi maka sangat dibutuhkan sistem administrasi yang dapat menyajikan informasi secara efektif dan akurat.

Selain itu administrasi yang berhasil dapat membuat orang-orang yang terkait di dalamnya bekerjasama sesuai dengan tugas, wewenang dan tanggung jawabnya. PT. Pelayaran Nasional Indonesia (Persero) Cabang Surabaya sebagai badan usaha yang memberikan felayanan berupa jasa transportasi laut merupakan salah satu perusahaan yang sumber pendapatan terbesarnya berasal dari hasil penjualan tiket kapal yang dioperasikannya. Oleh karena itu, pelayanan yang baik dan penyajian informasi penjualan tiket kapal yang efektif dan akurat dalam perusahaan ini menjadi salah satu bagian penting yang menentukan perkembangan perusahaan. Maka dari itu penelitian mengenai administrasi dan tanggung jawab petugas tiket kapal jasa transportasi laut terhadap kepuasan penumpang pada PT. Pelayaran Nasional Indonesia (Persero) Cabang Surabaya perlu dilakukan. 


\section{LANDASAN TEORI DAN PENGEMBANGAN HIPOTESIS}

\section{Pelayanan Administrasi}

Menurut Bharata (2013) pelayanan adalah suatu kegiatan atau urutan kegiatan yang terjadi dalam interaksi langsung antara seseorang dengan orang lain atau mesin secara fisik, dan menyediakan kepuasan pelanggan. Berdasarkan beberapa pendapat diatasdapat disimpulkan bahwa pelayanan adalah kegiatan yang bertujuan untuk memenuhi kebutuhan atau memberikan kepuasan kepada pelanggan melalui penawaran jasa (intangible) atau produk oleh penyedia layanan, sedangkan Administrasi adalah rangkaian aktivitas yang terdiri dari berbagai unsur yang diawali dari pemikiran dan kesepakatan antara dua orang atau lebih.

Menurut Zeithhaml, Parasuraman \& Berry (dalam Hardiansyah 2011) untuk mengetahui kualitas pelayanan yang dirasakan secara nyata oleh konsumen, ada indikator kualitas pelayanan yang terletak pada beberapa dimensi kualitas pelayanan, yaitu:

a. Kenampakan fisik (tangible)

b. Reliabilitas (Reability)

c. Responsif (Reponsiveness)

\section{Tanggung Jawab}

Tanggung jawab secara umum adalah kesadaran manusia akan tingkah laku atau perbuatan baik yang disengaja maupun yang tidak di sengaja. Tanggung jawab juga berarti berbuat sebagai perwujudan kesadaran akan kewajiban, Untuk mengukur tanggung jawab secara individual ada beberapa indikator yang digunakan. Menurut Robbin (2006) ada beberapa indikator:
a. Kualitas
b. Kuantitas
c. Ketepatan waktu

\section{Kepuasan Penumpang}

Tjiptono (2012) kepuasan pelanggan merupakan respon pelanggan terhadap evaluasi persepsi atas perbedaan antara harapan awal sebelum pembelian (atau standar kinerja lainnya) dan kinerja aktual produk sebagaimana dipersepsikan setelah memakai atau mengkonsumsi produk bersangkutan, Kepuasan konsumen terbagi menjadi 2 yaitu (Admin, 2009)

a. Kepuasan Fungsional

b. Kepuasan Psokologi

Berdasarkan uraian tersebut maka hipotesis yang dibuat penulis pada penelitian ini adalah:

H1: Pelayanan administrasi memiliki hubungan yang signifikan terhadap kepuasan penumpang pada PT. Pelayaran Nasional Indonesia cabang Surabaya.

H2: Tanggung Jawab petugas tiket memiliki hubungan yang signifikan terhadap kepuasan penumpang pada PT. Pelayaran Nasional Indonesia cabang Surabaya.

H3: Pelayanan administrasi dan tanggung jawab petugas tiket secara bersama-sama (simultan)memiliki hubungan yang signifikan terhadap kepuasan penumpang pada PT. Pelayaran Nasional Indonesia cabang Surabaya.

\section{METODOLOGI PENELITIAN}

Variabel dalam penelitian ini meliputi:

1. Pelayanan administrasi $\left(\mathrm{X}_{1}\right)$

Untuk mengetahui aktivitas pelayanan yang dirasakan secara nyata oleh konsumen, ada indikator kualitas pelayanan yang terletak pada beberapa dimensi kualitas pelayanan yaitu :
a. Kenampakan fisik
b. Reliabilitas
c. Responsif

2. Tanggung jawab $\left(\mathrm{X}_{2}\right)$

Tanggung jawab yaitu kesadaran manusia akan tingkah laku, perbuatan baik yang disengaja maupun tidak disengaja. Tanggung jawab berarti berbuat sebagai perwujudan kesadaran akan kewajiban, adapun beberapa indikator yang digunakan yaitu : 

a. Kualitas
b. Kuantitas
c. Ketepatan waktu

3. Kepuasan penumpang (Y)

Kepuasan penumpang merupakan respon penumpang terhadap evaluasi presepsi atas perbedaan antara harapan awal sebelum pembelian dan kinerja aktual jasa sebagaimana dipresepsikan setelah menggunakan jasa tersebut. Kepuasan penumpang terbagi menjadi 2 yaitu :

a. Kepuasan fungsioner

b. Kepuasan psikologi

Jenis pendekatan penelitian dalam studi ini yaitu jenis kuantitatif yang dapat diartikan sebagai metode penelitian berdasarkan filsafat positivisme, meliputi penelitian pada populasi dan sampel, pengumpulan data menggunakan instrumen penelitian, analisis data bersifat kuantitatif dengan tujuan untk menguji hipotesis. Populasi dalam penelitian ini adalah seluruh penumpang pada PT. Pelayaran Nasional Indonesia yang berjumlah 128 penumpang. Selanjutnya dengan menggunakan rumus slovin didapatkan jumlah sampel sebanyak 56 penumpang. Adapun metode analisis data yang digunakan dalam penelitian ini adalah analisis regresi linear berganda, dengan sebelumnya menguji kualitas data yang diperoleh dengan menggunakan uji validitas dan uji reliabilitas serta uji hipotesis.

\section{HASIL PENELITIAN}

Uji validitas dan uji reliabilitas

a. Uji validitas

Tabel 1. Hasil uji validitas pelayanan administrasi $\left(\mathbf{X}_{1}\right)$

\begin{tabular}{cccc}
\hline Pernyataan/pertanyaan & $\mathbf{r}_{\text {hitung }}$ & $\mathbf{r}_{\text {tabel }}$ & kesimpulan \\
\hline $\mathrm{X}_{1 .} 1$ & 0,433 & 0,263 & Valid \\
$\mathrm{X}_{1} 2$ & 0,571 & 0,263 & Valid \\
$\mathrm{X}_{1.3}$ & 0,511 & 0,263 & Valid \\
$\mathrm{X}_{1} 4$ & 0,554 & 0,263 & Valid \\
\hline
\end{tabular}

Sumber : hasil pengelolaan data menggunakan SPSS 20, 2021

Tabel 2. Hasil uji validitas tanggung jawab $\left(X_{2}\right)$

\begin{tabular}{cccc}
\hline Pernyataan/pertanyaan & $\mathbf{r}_{\text {hitung }}$ & $\mathbf{r}_{\text {tabel }}$ & Kesimpulan \\
\hline X1.1 & 0,564 & 0,263 & Valid \\
X1.2 & 0,662 & 0,263 & Valid \\
X1.3 & 0,480 & 0,263 & Valid \\
X1.4 & 0,582 & 0,263 & valid
\end{tabular}

Sumber : hasil pengelolaan data menggunkaan SPSS 20, 2021 
Table 3. Hasil uji validasi kepuasan penumpang (Y)

\begin{tabular}{cccc}
\hline Pernyataan/pertanyaan & $\mathbf{r}_{\text {hitung }}$ & $\mathbf{r}_{\text {tabel }}$ & Kesimpulan \\
\hline Y1 & 0,395 & 0,263 & Valid \\
Y2 & 0,547 & 0,263 & Valid \\
Y3 & 0,644 & 0,263 & Valid \\
Y4 & 0,610 & 0,263 & valid
\end{tabular}

Sumber : hasil pengelolaan data menggunakan SPSS 20,2021

Berdasarkan tabel diatas, dapat dilihat bahwa nilai $r_{\text {hitung }}$ untuk masing-masing variabel bertanda $>r_{\text {tabel }}$ yaitu menunjukkan bahwa data tersebut valid.

\section{b. Uji reliabilitas}

Untuk menguji keandalan (reliabel) suau pernyataan digunakan teknik analisis Cronbach Alpha untuk tiap variabel penelitan melalui program SPSS 20. Hasil pengujian ini dapat dikatakan reliabel apabila Cronbach Alpha $>0,60$.

Table 4. Hasil Uji reliability

\begin{tabular}{cccc}
\hline Variabel & Cronbach Alpha & Kriteria & Kesimpulan \\
\hline Pelayanan administrasi & 0,335 & 0,6 & Reliabel \\
Tanggung jawab & 0,294 & 0,6 & Reliabel \\
Kepuasan penumpang & 0,206 & 0,6 & Reliabel
\end{tabular}

Sumber : hasil pengelolaan data menggunakan SPSS 20,2021

Berdasarkan tabel diatas bahwa nilai Cronbach Alpha dari variabel pelayanan administrasi $\left(\mathrm{X}_{1}\right)$, tanggung jawab $\left(\mathrm{X}_{2}\right)$, dan kepuasan penumpang $(\mathrm{Y})$ lebih besar 0,6 sehingga dapat disimpulkan bahwa data telah reliabel yang berarti kuesioner dapat digunakan.

\section{Uji asumsi klasik}

\section{Uji normalitas}

Uji normalitas mempunyai tujuan untuk mengetahui apakah variabel bebas dan variabel terikat mempunyai distribusi normal atau tidak .

a. Uji One-Sample Kolmogrov-Smimov

Table 5. Hasil uji One-Sample Kolmogrov-Smimov

\begin{tabular}{cc}
\hline Asymp.sig (2 - tailed) & Alpha \\
\hline 0,982 & 0,05 \\
\hline
\end{tabular}

Sumber : hasil pengelolaan data menggunakan SPSS 20, 2021

Hasilnya bahwa nilai Asymp.sig (2 - tailed) sebesar 0,982 karena nilai diatas 0,05 maka distribusi data dinyatakan memenuhi asumsi normalitas. 
b. Uji normalitas probability plot

\section{Normal P-P Plot of Regression Standardized Residual}

\section{Dependent Variable: Y}

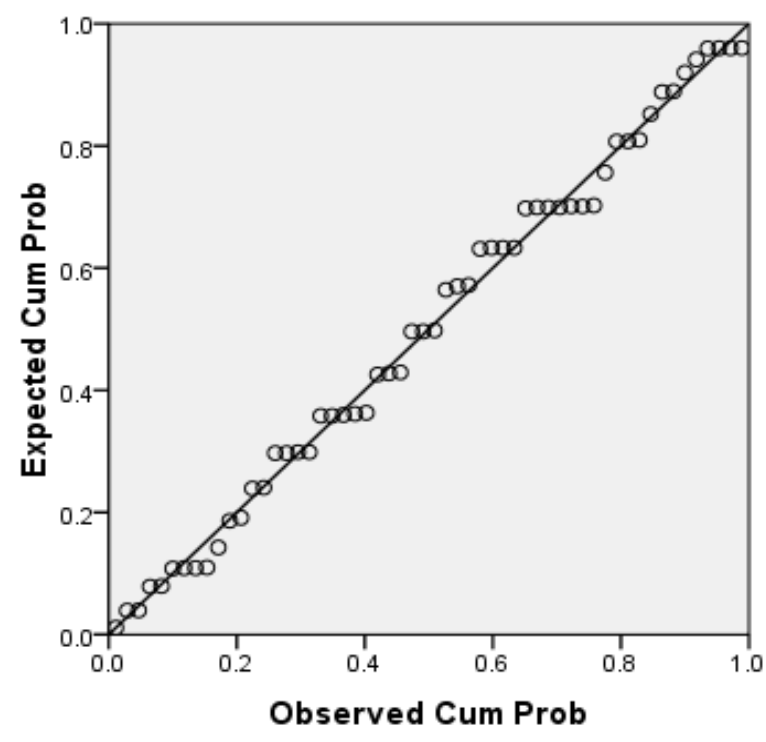

Gambar 2. Hasil Uji Normalitas

Dapat dilihat bahwa titik-titik yang ada selalu mengikuti dan mendekati garis diagonanya. Oleh karena itu dapat disimpulkan bahwa nilai residual berdistribusi normal sehingga syarat normalitas nilai residual untuk analisis regresi dapat dipenuhi.

\section{Uji heteroskedastisitas}

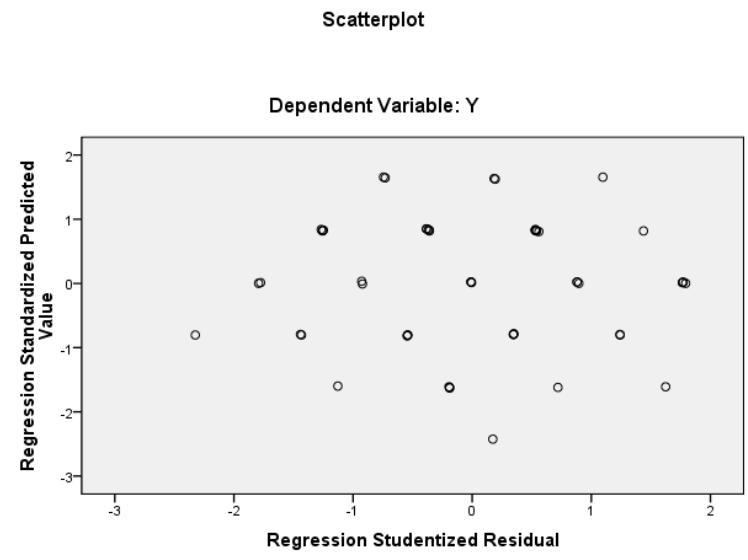

Gambar 3. Hasil uji Heterokedastisitas

Terlihat bahwa titik-titik menyebar dan tidak membentuk pola tertentu yang jelas, sehingga dapat disimpulkan bahwa tidak terjadi masalah heterokedastisitas. 


\section{Uji multikolinearitas}

Table 6. Hasil Uji Multikolinearitas

\begin{tabular}{cccc}
\hline Variabel & Toleransi & Sig. & Kesimpulan \\
\hline Pelayanan administrasi & 0,950 & 1,053 & Tidak terjadi multikolerasi \\
Tanggung jawab & 0,950 & 1,053 & Tidak terjadi multikolerasi \\
\hline
\end{tabular}

Sumber : hasil pengelolaan data menggunakan SPSS 20,2021

Nilai toleransi semua variabel lebih dari 0,1 dan nilai VIF kurang dari 10 sehingga dapat disimpulkan bahwa data dari penelitian ini tidak mengalami multikolinearitas antar variabel bebas.

\section{Uji linearitas}

Table 7. Hasil Uji Linearitas

\begin{tabular}{ccc}
\hline Linearity & Sig & Kesimpulan \\
\hline Pelayanan administrasi & 0,010 & Linier \\
Tanggung jawab & 0,010 & Linier \\
\hline
\end{tabular}

Sumber : hasil pengelolaan data menggunakan SPSS 20,2021

Dapat dilihat bahwa signifikansi lebih kecil dari $0,05(0,00<0,05)$ maka dapat disimpulkan bahwa antara variabel pelayanan administrasi dan kepuasan penumpang, tanggung jawab, kepuasan penumpang terdapat hubungan yang linear maka asumsi linearitas terpenuhi.

\section{Analisis regresi linear berganda}

Tabel 8. Hasil Uji Analisis Regresi Linier Berganda

\begin{tabular}{|c|c|c|c|c|}
\hline Model & $\begin{array}{c}\text { Unstandardized } \\
\text { Coefficients } \\
\text { B }\end{array}$ & $\begin{array}{c}\text { Standardized } \\
\text { Coefficients } \\
\text { Beta }\end{array}$ & $\mathbf{T}$ & Sig. \\
\hline (Constant) & 10,922 & & 3,490 & 0,001 \\
\hline $\begin{array}{l}\text { Pelayanan Administrasi } \\
\qquad\left(\mathrm{X}_{1}\right)\end{array}$ &,- 005 &,- 004 &,- 034 & 0,973 \\
\hline Tanggung Jawab $\left(\mathrm{X}_{2}\right)$ & 0,399 & 0,401 & 3,105 & 0,003 \\
\hline
\end{tabular}

Sumber : hasil pengelolaan data menggunakan SPSS 20,2021

Berdasarkan hasil perhitungan tersebut diperoleh persamaan regresi linear berganda yang signifikan.

$\mathbf{Y}=\mathbf{1 0 , 9 2 2}+-, 005 \mathrm{X}_{1}+\mathbf{0 , 3 9 9} \mathrm{X}_{\mathbf{2}}+\mathrm{e}$

Interprestasi dari model regresi diatas adalah sebagai berikut :

1. Konstanta $\propto$ yang dihasilkan sebesar 10,922 menunjukkan bahwa besarnya nilai kepuasan penumpang (Y) sebesar 10,922 jika pelayanan administrasi $\left(\mathrm{X}_{1}\right)$, tanggung jawab $\left(\mathrm{X}_{2}\right)$ adalah konstanta.

2. Nilai koefisiensi pelayanan administrasi $\left(\beta_{1}\right)$ sebesar -,005 menunjukkan bahwa jika variabel pelayanan administrasi menurun, maka akan mengakibatkan peningkatan kepuasan penumpang sebesar 0,005 dan variabel lainnya bernilai nol.

3. Nilai koefisiensi tanggung jawab $\left(\beta_{2}\right)$ sebesar 0,399 menunjukkan bahwa jika variabel tanggung jawab meningkat, maka akan mengakibatkan peningkatan kepuasan penumpang sebesar 0,399 dan variabel lain bernilai nol. 


\section{Uji hipotesis}

\section{Uji parsial (t)}

Uji t suatu uji untuk mengetahui signifikan pengaruh variabel bebas (pelayanan administrasi, tanggung jawab) secara parsial atau individual terdapat variabel terikat (kepuasan penumpang).

1. Perumusan hipotesis untuk uji $\mathrm{t}$ (parsial) pada variabel pelayanan administrasi $\left(\mathrm{X}_{1}\right)$ :

a. $\mathrm{H}_{0}=0$

$\mathrm{H}_{1} \neq 0$

Atau

$\mathrm{H}_{0}$ : variabel bebas pelayanan administrasi $\left(\mathrm{X}_{1}\right)$ tidak berpengaruh signifikan secara parsial terhadap kepuasan penumpang $(\mathrm{Y})$

$\mathrm{H}_{1}$ : variabel bebas pelayanan administrasi $\left(\mathrm{X}_{1}\right)$ berpengaruh signifikan secra parsial terhadap kepuasan penumpang $(\mathrm{Y})$.

b. Jika nilai signifikansi variabel bebas pelayanan administrasi $\left(X_{1}\right)$ pada uji $t$ sig $<0,05$ atau $t_{\text {hitung }}>t_{\text {tabel }}$ maka terdapat pengaruh $\mathrm{X}$ terhadap $\mathrm{Y}$, jika $\mathrm{t}$ sig $>0,05$ atau $\mathrm{t}_{\text {hitung }}<\mathrm{t}_{\text {tabel }}$ maka tidak terdapat pengaruh variabel $\mathrm{X}$ terhadap $\mathrm{Y}$.

c. $\mathrm{T}_{\text {tabel }}=\mathrm{t}(\propto / 2 ; \mathrm{n}-\mathrm{k}-1)$

$$
\begin{aligned}
& =0,05 / 2 ; 56-2-1 \\
& =0,025 ; 53 \\
& =2,005
\end{aligned}
$$

Analisis uji $\mathrm{T}$ adalah besarnya nilai $\mathrm{t}_{\text {hitung }}$ pada variabel pelayanan administrasi $\mathrm{X}_{1}$ adalah sebesar -,034 dengan tingkat signifikan 0,973, karena -,034 < 2,005 dan 0,973>0,005 maka menunjukkan bahwa $\mathrm{H}_{0}$ diterima dan $\mathrm{H}_{1}$ ditolak. Maka dapat disimpulkan variabel bebas pelayanan administrasi $\left(\mathrm{X}_{1}\right)$ tidak berpengaruh signifikan terhadap kepuasan penumpang $(\mathrm{Y})$

2. Perumusan hipotesis untuk pengujian $\mathrm{T}$ (parsial) pada variabel tanggung jawab $\left(\mathrm{X}_{2}\right)$ :

$$
\text { a. } \begin{aligned}
\mathrm{H}_{0} & =0 \\
\mathrm{H}_{1} & \neq 0
\end{aligned}
$$

Atau

$\mathrm{H}_{0}$ : variabel bebas tanggung jawab $\left(\mathrm{X}_{2}\right)$ tidak berpengaruh signifikan secara parsial terhadap kepuasan penumpang (Y).

$\mathrm{H}_{1}$ : variabel bebas tanggung jawab $\left(\mathrm{X}_{2}\right)$ berpengaruh signifikan secara parsil terhadap kepuasan penumpang (Y).

b. Jika nilai signifikan variable bebas tanggung jawab $\left(\mathrm{X}_{2}\right)$ pada uji $\mathrm{t}$ sig $<0,05$ atau $\mathrm{t}_{\text {hitung }}>\mathrm{t}_{\text {tabel }}$ maka terdapat pengaruh $\mathrm{X}$ terhadap $\mathrm{Y}$. Jika nilai sig $>0,05$ atau $t_{\text {hitung }}<\mathrm{t}_{\text {tabel }}$ maka tidak terdapat pengaruh variabel $\mathrm{X}$ terhadap $\mathrm{Y}$.

c. $\quad \mathrm{T}_{\text {tabel }}=\mathrm{t}(\propto / 2 ; \mathrm{n}-\mathrm{k}-1)$

$$
=0,05 / 2 ; 56-2-1
$$$$
=0,025 ; 53
$$$$
=2,005
$$

Analisis uji $\mathrm{t}$ adalah besarnya nilai $\mathrm{t}_{\text {hitung }}$ pada variabel tanggung jawab $\left(\mathrm{X}_{2}\right)$ adalah sebesar 3,105 dengan tingkat signifikan 0,001. Karena 3,105 > 2,005 dan 0,003 < 0,05 maka menunjukkan bahwa $\mathrm{H}_{0}$ ditolak dan $\mathrm{H}_{1}$ diterima. Maka dapat disimpulkan variabel bebas tanggung jawab $\left(\mathrm{X}_{2}\right)$ berpengaruh signifikan secara parsial terhadap kepuasan penumpang (Y).

\section{Uji Simultan (Uji F)}

Tabel 9. Hasil Uji F

\begin{tabular}{ccc} 
Model & F & Sig \\
\hline 1 & 5,050 & 0,010 \\
\hline
\end{tabular}

Sumber : hasil pengelolaan data menggunakan SPSS 20,2021

Perumusan hipotesis untuk uji F (simultan)

a. $\mathrm{H}_{0}=0$

$\mathrm{H}_{1} \neq 0$

Atau

$\mathrm{H}_{0}$ : seluruh variabel bebas yang terdiri dari pelayanan administrasi $\left(\mathrm{X}_{1}\right)$, dan tanggung jawab $\left(\mathrm{X}_{2}\right)$ tidak berpengaruh signifikan secara simultan terhadap kepuasan penumpang (Y). 
$\mathrm{H}_{1}$ : Seluruh variabel bebas yang terdiri dari pelayanan administrasi $\left(\mathrm{X}_{1}\right)$, tanggung jawab $\left(\mathrm{X}_{2}\right)$ berpengaruh signifikan secara simulatan terhadap kepuasan penumpang $(\mathrm{Y})$.

Jika nilaisignifikansi dari uji $\mathrm{F}$ sig $<0,05$ atau $\mathrm{f}_{\text {hitung }}>\mathrm{f}_{\text {tabel }}$ maka terdapat pengaruh variabel $\mathrm{X}$ secara simultan terhadap $\mathrm{Y}$ jika nilai sig $>0,05$ atau $\mathrm{f}_{\text {hitung }}<\mathrm{f}_{\text {tabel }}$ maka tidak terdapat pengaruh variabel $\mathrm{X}$ secara simultan terhadap variabel $\mathrm{Y}$.

b. $\mathrm{F}_{\text {tabel }}=\mathrm{k} ; \mathrm{n}-\mathrm{k}$

$=2 ; 56-2$

$=2 ; 54$

$=3,17$

Uji $F$ didapatkan $f_{\text {hitung }}$ sebesar 5,050 dengan tingkat signifikansi 0,010. Karena $f_{\text {hitung }}>f_{\text {tabel }}(5,050>3,17$ dan tingkat signifikannya $0,010<0,05$ maka dapat menunjukka bahwa $\mathrm{H}_{0}$ ditolak dan $\mathrm{H}_{1}$ diterima.

Kesimpulan : variabel bebas pelayanan administrasi $\left(\mathrm{X}_{1}\right)$, tanggung jawab $\left(\mathrm{X}_{2}\right)$ berpengaruh signifikan secara simultan terhadap kepuasan penumpang (Y).

Uji Koefisiensi Determinasi

Tabel 10. Hasil Uji Koefisien Determinasi

\begin{tabular}{ccccc}
\hline Model & R & R Square & Adjusted R Square & $\begin{array}{c}\text { Std.Error of the } \\
\text { Estimate }\end{array}$ \\
\hline 1 &, 400 &, 160 &, 128 & 1,140 \\
\hline
\end{tabular}

Sumber : hasil pengelolaan dengan menggunakan SPSS 20,2021

Dari table diatas menunjukkan $\mathrm{R}$ sebesar 0,400 menunjukkan bahwa hubungan korelasi antara pelayanan administrasi dengan variabel tanggung jawab dan kepuasan penumpang adalah kuat nilai koefisiensi determinasi berganda Adjusted R adalah 0,128 hal ini berarti 12,8 \% variasi kepuasan penumpang dapat dijelaskan dari dua variabel independen yaitu pelayanan administrasi dan tanggung jawab sedangkan sisanya dijelaskan oelh variabel-variabel diluar model.

\section{PEMBAHASAN}

\section{Pelayanan Administrasi (X1) terhadap Kepuasan Penumpang (Y)}

Masalah pelayanan administrasi dan tanggung jawab sangat penting untuk memperhatikan dalam mempengaruhi kepuasan penumpang karena memiliki hubungan yang signifikan terhadap kepuasan penumpang. Hal ini dibuktikan bahwa hasil penelitian yang menunjukkan bahwa nilai $\mathrm{f}_{\text {hitung }} 5,050>\mathrm{f}_{\text {tabel }} 3,17$ dan tingkat signifikannya $0,010<\propto 0,05$ yang berarti secara keseluruhan variabel memiliki hubungan terhadap variabel kepuasan penumpang. Hasil perhitungan menggunakan analisis regresi linier berganda pada uji t, diperoleh nilai koefisiensi regresi untuk masing-masing variabel bebas adalah -,005 untuk pelayanan administrasi $\left(\mathrm{X}_{1}\right)$ dan 0,399 untuk tanggung jawab $\left(\mathrm{X}_{2}\right)$ nilai koefisiensi regresi yang positif menunjukkan bahwa hubungan dari masing-masing variabel bebas adalah positif.

Hasil penelitian menunjukkan bahwa variabel pelayanan administrasi $\left(\mathrm{X}_{1}\right)$ tidak memiliki hubungan yang signifikan terhadap kepuasan penumpang $(Y)$ dengan $t_{\text {hitung }}$ sebesar -0,034 lebih kecil $t_{\text {tabel }}$ sebesar 0,401 dengan tingkat signifikansi lebih besar dari 0,05 itu artinya bahwa hipotesis ke-1 dalam penelitian ini tidak terbukti kebenarannya atau dapat diterima sehingga pelayanan administrasi $\left(\mathrm{X}_{1}\right)$ tidak berpengaruh terhadap kepuasan penumpang (Y). Kemampuan perusahaan untuk memberikan pelayanan sesuai yang di janjikan secara akurat dan terpercaya, kinerja harus sesuai dengan harapan pelanggan yang berarti ketepatan waktu, pelayanan yang sama untuk semua pelanggan tanpa kesalahan, sifat yang simpatik. Meskipun pelayanan administrasi tidak baik akan tetapi sebagian dari pelanggan tetap memakai jasa transportasi laut di PT.Pelayanan Nasional Indonesia. Jika pelayanan administrasi ditingkatkan maka akan juga dapat meningkatkan kepuasan pelanggan meskipun begitu, sepertinya dari pelayanan yang diberikan tidak secara menyeluru dirasakan oleh para penumpang sehingga tidak terlalu memberi pengaruh yang signifikan bagi kepuasan penumpang seperti ketepatan waktu.

Dapat disimpulkan bahawa ketika peningkatan pelayanan administrasi yang semakin baik/buruk, maka semakin besar pula kepuasan pelanggan, akan tetapi tidak terjadi pengaruh yang signifikan pada hasil penelitian ini, hal ini sejalan dengan penelitian dari Sukmawati (2011) yang menunjukkan bahwa pelayanan administrasi tidak berpengaruh melainkan kebutuhan yang menjadi komitmen penumpang bertahan secara mendalam untuk 
berlangganan kembali atau melakukan pembelian ulang produk dan jasa, meskipun pemasaran mempunyai potensi untuk menyebabkan perubahan perilaku.

\section{Tanggung Jawab $\left(\mathbf{X}_{2}\right)$ terhadap Kepuasan Penumpang (Y)}

Hasil penelitian menunjukkan bahwa variabel tanggung jawab $\left(\mathrm{X}_{2}\right)$ memiliki hubungan yang signifikan terhadap kepuasan penumpang $(\mathrm{Y})$, dengan $\mathrm{t}_{\text {hitung }} 3,105$ lebih besar dari $\mathrm{t}_{\text {tabel }} 2,005$, tingkat signifikan lebih kecil lebih kecil dari 0,05. Dari hasil tersebut maka hipotesis ke-2 terbukti kebenarannya dan dapat diterima sehingga tanggung jawab $\left(\mathrm{X}_{2}\right)$ berpengaruh signifikan secara parsial terhadap kepuasan penumpang (Y). Petugas tiket yang memiliki tanggung jawab yang lebih maka akan menimbulkan kepuasan penumpang. Disimpulkan bahwa tanggung jawab para petugas tiket yang dilakukan semakin baik maka semakin besar pula kepuasan pelanggan terhadap jasa yang diberikan perusahaan, dan tanggung jawab yang di berikan petugas tiket terhadap pelanggan berupa menjawab pertanyaan pelanggan, tugas melakukan pemeriksaan tiket dengan cepat dan tepat, menyapa menumpang dengan lembut, berperilaku sopan dan hormat mampu meyakinkan penumpang pelanggan dalam bemberikan kepuasan,dll. Pernyataan tersebut didukung oleh penelitian dari Zulvi (2015) yang menyatakan tanggung jawab petugas semakin baik, maka perlu dilakukan upaya untuk terus meningkatkan kualitas petugas/Tanggung jawab petugas selama memberikan pelayanan ke penumpang.

\section{Pengaruh Pelayanan Administrasi $\left(X_{1}\right)$ dan Tanggung Jawab $\left(X_{2}\right)$ Terhadap Kepuasan Penumpang $(\mathbf{Y})$}

Jika nilai signifikansi dari uji $\mathrm{F} \mathrm{Sig}<0,05$ atau $\mathrm{F}_{\text {hitung }}>\mathrm{F}_{\text {Tabel }}$ maka terdapat pengaruh variabel X secara simultan terhadap Y. Jika nilai sig $>0,05$ atau $\mathrm{F}_{\text {hitung }}<\mathrm{F}_{\text {tabel }}$ maka tidak terdapat pengaruh variabel X secara simultan terhadap variabel $\mathrm{Y}$. Uji ANOVA atau $\mathrm{F}$ didapatkan $\mathrm{F}_{\text {hitung }}$ sebesar 5,050 dengan tingkat signifikansi 0,010. Karena $F_{\text {hitung }}>F_{\text {tabel }}(5,050>3,17$ dan tingkat signifikan $0,010<0,05$ maka dapat menunjukkan bahwa $\mathrm{H}_{0}$ ditolak $\mathrm{H}_{1}$ diterima. Kesimpulannya variabel bebas pelayanan administrasi $\left(\mathrm{X}_{1}\right)$, tanggung jawab $\left(\mathrm{X}_{2}\right)$ berpengaruh signifikan secara simultan terhadap kepuasan penumpang $(\mathrm{Y})$.

Perusahaan yang memiliki pelayanan administrasi yang bagus dan petugas tiket yang memiliki tanggung jawab yang baik maka dapat meningkatkan kepuasan penumpang sehingga pelanggan akan tetap setia menggunakan jasa transportasi laut di PT. Pelayaran Nasional Indonesia untuk pelayaran selanjutnya. Pada hasil penelitian ini, hal ini sejalan dengan penelitian dari Sukmawati (2011) yang menunjukkan bahwa pelayanan administrasi tidak berpengaruh melainkan kebutuhan yang menjadi komitmen penumpang bertahan secara mendalam untuk berlangganan kembali atau melakukan pembelian ulang produk dan jasa, meskipun pemasaran mempunyai potensi untuk menyebabkan perubahan perilaku. Sedangkan Pernyataan tersebut didukung oleh penelitian dari Zulvi (2015) yang menyatakan tanggung jawab petugas semakin baik, maka perlu dilakukan upaya untuk terus meningkatkan kualitas petugas/tanggung jawab petugas selama memberikan pelayanan ke penumpang.

\section{KESIMPULAN DAN SARAN}

Berdasarkan hasil penelitian tentang Pelayanan administrasi dan tanggung jawab terhadap kepuasan penumpang yang dilakukan di PT.Pelayaran Nasional Indonesia Cabang Surabaya maka dapat disimpulkan halhal sebagai berikut :

1. Variabel pelayanan administrasi $\left(X_{1}\right)$ tidak memiliki hubungan yang signifikan terhadap kepuasan penumpang (Y), artinya pelayanan administrasi yang baik/buruk tidak akan meningkatkan kepuasan pelanggan.

2. Variabel tanggung jawab $\left(\mathrm{X}_{2}\right)$ memiliki hubungan yang signifikan terhadap kepuasan penumpang (Y) jika tanggung jawab petugas tiket baik maka kepuasan pelanggan akan semakin meningkat.

3. Secara bersama-sama (simultan) variabel pelayanan administrasi $\left(\mathrm{X}_{1}\right)$ dan tanggung jawab $\left(\mathrm{X}_{2}\right)$ memiliki hubungan yang signifikan terhadap variabel dependen yaitu kepuasan penumpang $(\mathrm{Y})$ jika pelayanan administrasi baik dan tanggung jawab penugas tiket baik maka pelanggan akan semakin puas.

Saran ke depannya untuk di PT.Pelayaran Nasional Indonesia Cabang Surabaya adalah sebagai berikut:

1. Perusahaan harus terus meningkatkan kualitas petugas/tanggung jawab petugas selama memberikan pelayanan ke penumpang.

2. Perusahan perlu meningkatkan pelayanan administrasi yang bagus agar loyalitas konsumen terbentuk kuat. 


\section{DAFTAR PUSTAKA}

Admin. 2009. Pelayanan Prima Untuk Pelanggan. On-line.

Barata, Atep Adya. 2013. Dasar-Dasar Pelayanan Prima. Jakarta: PT. Alex Media Komputindo.

Ghozali, Imam. 2013. Aplikasi Analisis Multivariate Dengan Program SPSS. Edisi Ketujuh. Semarang: Badan Penerbit Universitas Diponegoro.

Hardiansyah. 2011. Kualitas Pelayanan Publik. Yogyakarta : Gava Media.

Kasmir. 2005. Etika Customer Service. Raja Grafindo Persada. Jakarta.

Kotler, Philip. 2007. Manajemen Pemasaran, Jilid 2. PT. Indeks. New Jersey.

Nazir, Moh. 2013. Metode Penelitian. Bogor : Ghalia Indonesia.

Priyatno, Dwi. 2012. Cara Kilat Belajar Analisis Data Dengan SPSS 20. Edisi Kesatu. Yogyakarta: Andi Offset.

Sugiyono. 2010. Metode Penelitian Pendidikan Pendekatan Kualitatif, Kuantitatif dan R\&D. Bandung: Alfabeta.

Sugiyono. 2015. Metode Penelitian Kombinasi (Mix Methods). Bandung : Alfabeta.

Sukmawati, K. 2011. Pengaruh Kualitas Layanan, Harga, dan Kepuasan Pelanggan terhadap Loyalitas Pelanggan Jasa Transportasi Kereta Api Eksekutif. Jurnal Manajemen hal 116, Depok FE Universitas Guna Dharma.

Tjiptono, Fandy. 2010. Service Management : Mewujudkan Layanan Prima. Yogyakarta: Andi Offset. 